\title{
INTERNATIONAL HEALTH INVESTIGATIONS
}

$\mathrm{T}$ HE report to the Council of the League of Nations on the work of the thirty-first session of the Health Committee, November 20-24, 1939 (Special Supplement to Monthly Summary of the League of Nations, January, 1940), emphasizes the important duties of the Health Organisation under war-time conditions, particularly in view of the threats to health from movement of populations and evacuation.

The Committee agreed that the permanent health services should not be interrupted, particularly the Epidemiological Intelligence Service, the Singapore Bureau and the biological standardization work, the utility of which is universally acknowledged. It is also desirable to continue studies on which a considerable amount of work has already been carried out, such as the inquiry into the radiological treatment of cancer of the cervix uteri, the preparation for the unification of the various national pharmacopœias, the studies undertaken by the Malaria Commission on malaria immunity, and the biology of certain strains of Plasmodium, the co-ordination of investigations into nutrition in the East, and the analysis of the annual statistics of rabies. The Committee also considers that national committees and national institutes should be urged to continue their work on nutrition, physical fitness and housing, for which the Health Section will ensure the necessary liaison and co-ordination. It was considered that comparatively new studies, such as museums of hygiene, clothing and the preparation of an international list of diseases, must be relegated to the background for the present, and it was agreed that the impending Pan-African Health Conference should be deferred until the end of the War. The Antimalarial Drug Conference and the Rabies Conference have been similarly deferred.

In view of the repercussions the present War is likely to have on public health, the Health Committee considers that attention should be devoted to such questions as the importation of diseases into regions hitherto free, the possible contamination of drinking water, and lower standards of living and hygiene. The Emergency Sub-Committee and the Health Section have accordingly been authorized to take such action as circumstances require, including a stocktaking of the armoury of preventive and curative weapons made possible by modern epidemiology, chemotherapy and serotherapy. The Health Section proposes to define the principles which should be followed in the control of those epidemic diseases which are regarded as the most important in present circumstances, for example, immunization against diphtheria and scarlet fever. Other questions to which the Health Organization is prepared to give attention are the medico-social problems arising out of the evacuation of threatened populations from war zones, including questions of environmental hygiene among evacuated persons living in the reception areas and individual standards of hygiene, as well as problems of food supply requiring the application of the rules of modern dietetics in the use of foodstuffs and in collective and individual dietaries. In view of the considerably increased volume of work anticipated, the Committee directed the SecretaryGeneral's attention to the desirability of making at least some temporary increase in the staff.

The introduction of international biological standards by the Copenhagen and Hampstead Institutes has continued normally, and the number of institutes using these standards has increased. The Health Committee once more directed attention to the recommendation adopted by the Permanent Commission on Biological Standardisation in 1928 regarding nomenclature to be used in the designation of blood groups.

The report of the Housing Committee, which met at Geneva during June 26-July 1, 1939, to discuss the hygiene of the planning of space, the abatement of smoke, dust and toxic gases, water supply, sewage treatment, and the collection and treatment of domestic refuse, is being communicated to Governments, health administrations and the institutions concerned.

\section{RECENT AMERICAN WORK ON PLANT VIRUSES}

\footnotetext{
$\mathrm{T}$ HE meeting of the American Association for the Advancement of Science, which was held at Columbus, Ohio, in December, was the occasion for the presentation of several interesting papers which make fundamental contributions to our knowledge of plant virus diseases. The first categorical indication of structure of the virus particle can be obtained from a comparison of the work of John W. Gowen, of Iowa State College, with earlier findings. His work on X-ray inactivation and size of various organisms, including insects, bacteria and viruses, shows that functional correlation of these two factors "must be between the size of some vital substances within the cell rather than the cell as a whole". The 'repro-
}

ductive' part of a virus particle has a molecular weight of $15,000,000$, which compares with about $7,000,000$ suggested by other workers for the whole virus particle. The portion of a virus susceptible to inactivation by X-rays is apparently denser than the rest of the particle.

Vernon L. Frampton, of Cornell University, showed that the protein of tobacco mosaic virus is thixotropic; it forms a colloidal sol, but can change to the fluid state if it is agitated. The report consisted of motion pictures which recorded the birefringence of the sol as observed through polaroid plates. Thixotropic gels show neither Brownian movement; diffusion nor osmotic phenomena, and it is pointed 
out that any attempt to determine molecular weight of the protein by any of these means would yield abnormally large values.

In the sphere of host-virus relations, Ernest L. Spencer, of the Rockefeller Institute for Medical Research, demonstrated that the rate of virus multiplication is closely bound with the nitrogen metabolism of the host. Tobacco plants growing in pure culture, and supplied with a relatively large amount of nitrogen, allowed the virus to attain about five times the concentration found in normally fed plants. The effect was not due to an increased growth-rate of the plant, and it was also demonstrated with older seedlings. James M. Wallace, of Riverside, California, dealt with the development of resistance to the curly top virus of Turkish tobacco. He showed that plants recover from an attack by the virus, a certain time after inoculation. Such plants, when re-inoculated, do not again develop severe symptoms. Transmission from a recovered to a healthy plant by means of insect vectors induced severe symptoms in the healthy plants, but grafting merely transferred the mild symptoms typical of the recovered plants. Resistance, therefore, appears to be due to some interaction which is set up between host and virus.

\section{INDIAN SCIENCE CONGRESS ASSOCIATION*}

\section{MadRas MeEting}

\section{ASPECTS OF THE MYXOPHYCEAE}

Prof. Y. Bhâradwâja, presiding over the Section of Botany, considered the peculiar group of algæ known as the Myxophyceæ. These algæ present many problems, both economic and botanical, and in spite of the extensive literature there is scarcely any authoritative statement that can be made concerning any aspect of their study at the present time. Owing to the peculiar properties of their cells, many of them are able to exist under high-temperature conditions and are largely tropical in their distribution, so that India is a particularly suitable centre for their study. With the active investigations that are being carried out by Prof. Bhâradwâja and other algologists at Madras, Lahore and Benares, it is hoped that much light will be thrown upon their peculiar features.

A special interest of this group for India is the way in which the Myxophyceæ at times undergo extreme development and give rise to the condition known as 'water-bloom'. On death and decay, such masses of algæ give disagreeable tastes and odours to the water and may render it unfit for drinking purposes, in fact there are records from many parts of the world of serious effects produced upon man and animals by drinking such water. In India, waterblooms are of common occurrence in ponds, pools and tanks, the water of which is used for consumption by humans and domesticated animals; though no serious effects have so far resulted in India, it is obviously a subject requiring investigation. Such points as the conditions favouring the development of the blooms, the contributing organisms, methods of control, and the manner in which the organisms persist all require workers in India.

Prof. Bhâradwâja also directed attention to the problems played by Myxophyceæ in soil ecology. These algæ occur in considerable numbers in the soil flora and some of them, notably Nostoc and Anabæna, are capable of nitrogen-fixation. In the Indian rice fields, the same crop is grown year after year without addition of manure, and it has been discussed whether the vabundant development of these algæ during inundation may be a factor of any importance. Fritsch and De came to the conclusion that their part in this connexion was probably relatively insignificant, but the problem needs further study.
The Myxophyceæ are also in need of closer study and revision from the botanical point of view. In many cases the generic distinctions are unsatisfactory, as they are not applied logically and allow of too much intergrading. Their cytology has received considerable attention lately and most workers are now agreed that the central body may be regarded as a nucleus.

Systematic study of the group involves such problems as their relation to the isolated group of the Chamæsiphonales and also to the Bacteria, especially such types as the sulphur bacteria.

Prof. Bhâradwâja's address points out the wide scope for workers in this field, and his survey of the present position of knowledge of the group will be a valuable basis for anyone attracted to further the study of the Myxophycer.

\section{AIR-Breathing Fishes}

The presidential address to the Section of Zoology was delivered by Prof. B. K. Das.

In a comprehensive survey of present knowledge of the phenomenon of 'air-breathing' in fishes, Prof. Das developed the theory of structural adaptation in response to environmental change. "The habit of swallowing air," he says, "being long continued, becomes deeply engrained in the constitution of the species, generations after generations, and is gradually improved and eventually leads to structural modifications, usually in the form of reservoirs adapted to lodge the inhaled air. These reservoirs are of very different forms and quite independently evolved, in each and every species of fish. . . ."

Six main types were described of progressive adaptations, which are to be seen in modern airbreathing fishes, namely, modifications of the buccopharynx ; pharyngeal 'lung' ; opercular chambers; opercular 'lung'; specialized parts of the alimentary canal (stomach and intestine); and the air-bladder. These accessory respiratory organs are regarded as the physiological forerunners of the true lungs of the terrestrial vertebrates, evolved in consequence of a lack of oxygen in the water.

The views of Carter and Beadle are supported and quoted verbatim : ". . . A power of breathing air must have been a necessary preliminary to the possibility of migration to land. It appears probable 